\title{
Article \\ Ocean Acidification, but Not Environmental Contaminants, Affects Fertilization Success and Sperm Motility in the Sea Urchin Paracentrotus lividus
}

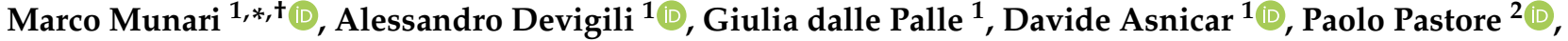 \\ Denis Badocco $^{2}$ and Maria Gabriella Marin ${ }^{1}$ D \\ 1 Department of Biology, University of Padova, Via Ugo Bassi 58/B, 35121 Padova, Italy; \\ alessandro.devigili@unipd.it (A.D.); giulia.dallepalle@gmail.com (G.d.P.); davide.asnicar@gmail.com (D.A.); \\ mgmar@bio.unipd.it (M.G.M.) \\ 2 Department of Chemical Sciences, University of Padova, Via Marzolo 1, 35131 Padova, Italy; \\ paolo.pastore@unipd.it (P.P.); denis.badocco@unipd.it (D.B.) \\ * Correspondence: marco.munari@szn.it \\ + Current address: Department of Integrative Marine Ecology, Ischia Marine Centre, \\ Stazione Zoologica Anton Dohrn, Punta San Pietro, 80077 Ischia (Naples), Italy.
}

check for

updates

Citation: Munari, M.; Devigili, A.; dalle Palle, G.; Asnicar, D.; Pastore, P.; Badocco, D.; Marin, M.G. Ocean Acidification, but Not Environmental Contaminants, Affects Fertilization Success and Sperm Motility in the Sea Urchin Paracentrotus lividus. J. Mar. Sci. Eng. 2022, 10, 247. https:// doi.org/10.3390/jmse10020247

Academic Editor: Romana Santos

Received: 30 December 2021

Accepted: 8 February 2022

Published: 11 February 2022

Publisher's Note: MDPI stays neutral with regard to jurisdictional claims in published maps and institutional affiliations.

Copyright: (C) 2022 by the authors. Licensee MDPI, Basel, Switzerland. This article is an open access article distributed under the terms and conditions of the Creative Commons Attribution (CC BY) license (https:// creativecommons.org/licenses/by/ $4.0 /)$.

\begin{abstract}
Ocean acidification poses an increasing concern for broadcast spawning species that release gametes in the water column where fertilization occurs. Indeed, the functionality of gametes and their interactions may be negatively affected by reduced $\mathrm{pH}$. Susceptibility to other environmental stressors, such as pollutants, may be also altered under acidified conditions, resulting in more detrimental effects. To verify this hypothesis, combined exposures to $\mathrm{CO}_{2}$-driven acidification and environmentally relevant concentrations $(0.5 \mu \mathrm{g} / \mathrm{L})$ of three contaminants (caffeine, diclofenac, and PFOS, all singularly or in mixture) were carried out to highlight potential negative effects on fertilization success and motility of sperm in the sea urchin Paracentrotus lividus. Our results showed a significant reduction in the percentage of fertilized eggs when sperm were pre-exposed to reduced $\mathrm{pH}$ (ambient $\mathrm{pH}$ minus 0.4 units) compared to that of controls (ambient, $\mathrm{pH}=8.1$ ). Sperm speed and motility also decreased when sperm were activated and then exposed at reduced $\mathrm{pH}$. Conversely, at both $\mathrm{pH}$ values tested, no significant effect due to the contaminants, nor of their interaction with $\mathrm{pH}$, was found on any of the biological endpoints considered.
\end{abstract}

Keywords: seawater acidification; aquatic pollutants; echinoderms; gametes; spermatozoa

\section{Introduction}

The increasing atmospheric concentration of carbon dioxide $\left(\mathrm{CO}_{2}\right)$, related to the consumption of fossil fuels, is considered the main cause for the ongoing climate changes. It has been increasing from the beginning of the Industrial Revolution at rates that have never occurred in the past millions of years [1,2]. Up to $50 \%$ of the emitted $\mathrm{CO}_{2}$ was uptaken by seawater worldwide $[3,4]$ resulting in ocean acidification (OA) and changes in the seawater carbonate system (SCS) [2]. Compared to that of preindustrial levels, surface $\mathrm{pH}$ values of oceans and seas already decreased by approximately $0.1 \mathrm{pH}$ units, and a further reduction of around $0.3-0.5 \mathrm{pH}$ units is expected before the end of the 21st century [5,6], with an increase in seawater acidity of $4.12 \%$ every 10 years [7]. OA, and the related changes in SCS, can induce dramatic changes in marine benthic ecosystems, as already demonstrated in natural acidified sites, leading to a significant reduction in biodiversity with a higher presence of photosynthetic organisms and a lower representation of calcareous species [8-11]. Furthermore, the OA-related stress is expected to combine with pollution, posing an even major threat to marine ecosystems [12-15], especially in coastal areas. Here, organisms can be exposed to a wide range of anthropogenic substances, including emerging contaminants with unknown environmental impacts, an aspect that 
raises increasing concern $[16,17]$. Laboratory and mesocosms experiments were carried out to test if OA can exacerbate the negative effects of different pollutants in several marine calcifying species including bivalves [18-24], echinoderms [25-27], and polychaetes [28-30] at both adult and larval stage. On the contrary, the effects of OA in combination with aquatic pollutants on gametes are still poorly studied. Nonetheless, it was observed that significant and persistent changes in environmental variables, such as $\mathrm{pH}$, might affect the normal reproductive success of different marine species including bivalves [31-33], sea urchins [34-38], corals [39-41], polychaetes [28,42], and also fish [43]. Marine broadcast spawners, such as echinoderms, might be particularly susceptible to OA and pollutants because of their reproductive strategy. Reproduction is a fundamental aspect of the life cycle of the organisms and any disruption on this key event may be highly deleterious for the sustainability of natural populations. Most marine invertebrates, including echinoderms, spawn their gametes directly into the water column [44], where sperm must secure male reproductive success. To accomplish this task, sperm have to swim toward the eggs, but during the journey they might be negatively affected by sea-water chemical-physical characteristics [45-48]. The few data about the effects of environmental contaminants on sperm motility in marine invertebrates include the effects of heavy metals. Fitzpatrick et al. [49] demonstrated that the exposure to $100 \mu \mathrm{g} / \mathrm{L}$ of copper significantly reduced the percentage of mobile sperm as well as their velocity in the bivalve Mytilus trossulus. Our knowledge, however, completely lacks information about the functionality of gametes in conditions simulating possible climate change scenarios (sea-water acidification, global warming, changes in salinity) in the presence of pollutants. In this study, we focused on the purple sea urchin Paracentrotus lividus (Lamarck, 1816) being widely used as a model species in several ecophysiological and ecotoxicological studies [50-53]. Furthermore, P. lividus has a key role in shaping benthic marine communities in both the Mediterranean Sea and the Atlantic Ocean [54-56], where it also represents an important commercial resource [57]. $P$. lividus is a gonochoric species [58] and its reproductive cycle is annual with three main phases: the growing phase (late autumn and winter), when reserve material is accumulated into the gonads; the maturation phase (spring and early summer), during which gametogenesis and spawning take place; and the spent/regenerating phase, during which phagocytes absorb relict gametes [59]. As previously said, climatic changes, such as OA, are not the only stressors marine organisms have to deal with. In this study we selected three environmental contaminants that are present worldwide: diclofenac (named as DFC, a nonsteroidal anti-inflammatory pharmaceutical, NSAID), caffeine (named as CAF, a widely used natural alkaloid in many formulations), and per-fluorooctane sulfonate (named as PFOS, a perfluoroalkyl substance, PFAS). DFC, a cyclooxygenase (COX)-1 and -2 inhibitor, is an anti-inflammatory drug (NSAID) commonly used in both human and veterinary medicine [16], and it can be found in different aquatic environments at a range of concentrations from $\mathrm{ng} / \mathrm{L}$ to $\mu \mathrm{g} / \mathrm{L}$ [60-65]. In the island of Mallorca, DFC concentrations up to $0.3 \mu \mathrm{g} / \mathrm{L}$ were found in surface waters close to the wastewater treatment plants [66]. Caffeine is considered as the most common stimulant consumed by humans $[67,68]$ and it was found in concentrations ranging from 0.14 to $1.6 \mu \mathrm{g} / \mathrm{L}$ in Boston Harbor seawater by Siegener and Chen [69]. PFOS is a perfluoroalkyl substance (PFAS) that was widely used in the recent past mostly as polymerization aids, in textile treatment, fire-fighting foams, semiconductors, and medical devices. It is found in marine environments and marine organisms sometimes far from contamination sources [70-72], and its effects are similar to persistent organic pollutants (POPs). For these reasons its usage in Europe was restricted since 2007 [73] and it was included in the Stockholm Convention list of POPs in 2009 [74]. In the UK, PFOS was found in surface water, sediment, drinking water, wastewater treatment plant effluent at concentrations of $0.138 \mu \mathrm{g} / \mathrm{L}, 53.1 \mu \mathrm{g} / \mathrm{L}, 0.063 \mu \mathrm{g} / \mathrm{L}$, and $5.29 \mu \mathrm{g} / \mathrm{L}$, respectively [75]. Despite the high consumption, the environmental occurrence, and in the case of PFOS also the persistency of these contaminants being well documented, their effects on aquatic organisms need to be investigated more deeply also in relation to the ongoing climate change. Regarding DFC and CAF, it was already observed in other 
marine invertebrates that their presence at environmentally relevant concentrations can exacerbate OA effects on several physiological parameters at different life stages [20-24] but specifically not on sea urchins' sperm performances. Regarding PFOS instead, it is completely unknown the combined effects that PFOS and reduced $\mathrm{pH}$ can have in any marine invertebrate species. Furthermore, these widely present environmental contaminants were never tested together before, nor in ambient $\mathrm{pH}$ or acidified conditions. The present study aimed to fill this gap by evaluating changes in sperm quality parameters (sperm swimming velocity and sperm motility) and fertilization ability in the sea urchin P. lividus during exposure to reduced $\mathrm{pH}$ and a set of these environmental contaminants, alone or in a mixture.

\section{Materials and Methods}

In this study, two sets of experiments were conducted: (i) the first set of three experiments aimed at highlighting spermotoxic effects through the evaluation of fertilization success; (ii) the second set of nine experiments focused on determining spermotoxic effects in terms of impaired sperm motility. Being the study focused on the direct effects on sperm, only they, and not eggs, were pre-exposed to the experimental conditions to exclude any possible confounding factor induced by the contaminants on the eggs. The experimental conditions tested refer to exposure to two different $\mathrm{pH}$ values, 8.1 (which corresponds to the current ambient average value, from now named as $\mathrm{pH}^{\mathrm{Amb}}$ ) and 7.7 (refers to the acidification conditions expected by the end of this century, from now named as $\mathrm{pH}^{-0.4}$ ), in the presence or absence of CAF, DFC and PFOS (as single contaminants or in a mixture) always at a concentration of $0.5 \mu \mathrm{g} / \mathrm{L}$. Contaminants concentrations were chosen based on data from literature as reported in the introduction. In particular, as regards the contaminants, in the first group of experiments, they were used only individually, in the second both individually and in a mixture. Filtered seawater (FSW, $0.45 \mu \mathrm{m}$ ) and stock solutions of the three contaminants in deionized water were always used for the preparation of the experimental solutions. The $\mathrm{pH}$ value was adjusted by the insufflation of gaseous $\mathrm{CO}_{2}$. All experiments were conducted at $22{ }^{\circ} \mathrm{C}$. Samples of FSW at both $\mathrm{pH}$, in the presence or the absence of the contaminants and their mixture, were collected to measure seawater carbonate chemistry variables (i.e., $\mathrm{pH}_{\mathrm{T}}$, total alkalinity, dissolved inorganic carbon, $\mathrm{pCO}_{2}$, and calcite and aragonite saturation state). The methods in detail are reported in Munari et al. [19], and results are available in Table 1.

\subsection{Animal Collection and Spawning}

P. lividus adults were collected manually by SCUBA divers at approximately $2 \mathrm{~m}$ depth inside the Venice Lagoon, nearby the city of Chioggia (geographical coordinates: $45^{\circ} 13^{\prime} 65^{\prime \prime} \mathrm{N}, 12^{\circ} 16^{\prime} 29^{\prime \prime}$ E) between April and June 2015. As soon as possible, the sampled specimens were transported in cooling boxes to the Hydrobiological Station 'Umberto D'Ancona' (University of Padova) in Chioggia (Venice), where the experiments were performed. Organisms were kept in a flow-through system and feed with Ulva sp. P. lividus is not a protected nor endangered species and all experimental procedures described by the guidelines of the European Union (Directive 609/86) were followed. Within five days of collection, P. lividus were induced to spawn by injection of 1-2 mL of $0.5 \mathrm{M} \mathrm{KCl} \mathrm{[76].}$ Eggs were collected into beakers $(500 \mathrm{~mL})$ of FSW at ambient pH. Sperm was collected dry and kept on ice until use.

\subsection{Quality and Concentration of Gametes}

Gamete quality and concentration were assessed according to the following protocol. Sperm: for each male $4 \mu \mathrm{L}$ of seminal fluid were diluted in $10,000 \mu \mathrm{L}$ of FSW and viability was checked under a microscope. If sperm were found to be inactive, the male was discarded. Four $\mu \mathrm{L}$ of $7 \%$ neutralized formalin in FSW was then added to each sample and the sperm count was carried out using a Buerker chamber. The number of sperm present in one $\mu \mathrm{L}$ of sperm collected was thus defined for each male. Eggs: the eggs of each 
female were filtered with a $100 \mu \mathrm{m}$ nylon mesh filter to retain impurities (algal fragments or pedicels), refiltered with a $20 \mu \mathrm{m}$ nylon mesh filter, and then resuspended in $400 \mathrm{~mL}$ of FSW. The quality (shape and size) of the eggs was checked under the microscope to exclude females with abnormal eggs thus reducing any maternal effect due to the egg quality. A $500 \mu \mathrm{L}$ aliquot of egg suspension was taken from each female and counted. All females that provided less than 100,000 eggs in 15 min of spawning were discarded.

Table 1. Seawater carbonate chemistry variables (mean values $\pm \mathrm{SE}$ ) throughout experiment. $\mathrm{TA}=$ total alkalinity; $\mathrm{DIC}=$ total dissolved inorganic carbon; $\mathrm{pCO}_{2}=\mathrm{CO}_{2}$ partial pressure; $\Omega_{\text {cal }}=$ calcite saturation state; $\Omega_{\text {arg }}=$ aragonite saturation state, $\mathrm{pH}^{\mathrm{Amb}}=\mathrm{pH} 8.1, \mathrm{pH}^{-0.4}=\mathrm{pH}$ 7.7, $\mathrm{CAF}=$ caffeine, $\mathrm{DFC}=$ diclofenac, $\mathrm{PFOS}=$ perfluorooctane sulfonate, $\mathrm{MIX}=$ mixture.

\begin{tabular}{cccccccc}
\hline \multicolumn{2}{c}{ Condition } & $\mathbf{p H}_{\mathbf{T}}$ & TA & DIC & pCO $_{2}$ & $\Omega_{\text {cal }}$ & $\Omega_{\text {arg }}$ \\
\hline & Control & $8.05 \pm 0.04$ & $2861.46 \pm 46.24$ & $2601.08 \pm 53.27$ & $512.91 \pm 58.24$ & $6.68 \pm 0.56$ & $4.39 \pm 0.38$ \\
& CAF & $8.11 \pm 0.04$ & $2832.90 \pm 7.91$ & $2543.37 \pm 24.11$ & $620.18 \pm 48.27$ & $6.29 \pm 0.56$ & $4.13 \pm 0.38$ \\
$\mathrm{pH}^{\mathrm{Amb}}$ & DFC & $8.10 \pm 0.03$ & $2856.98 \pm 6.34$ & $2581.88 \pm 25.74$ & $452.42 \pm 34.46$ & $7.01 \pm 0.43$ & $4.60 \pm 0.29$ \\
& PFOS & $8.12 \pm 0.03$ & $2834.08 \pm 19.01$ & $2549.24 \pm 31.18$ & $420.90 \pm 35.60$ & $7.35 \pm 0.41$ & $4.82 \pm 0.27$ \\
& MIX & $8.09 \pm 0.03$ & $2859.66 \pm 10.80$ & $2590.87 \pm 27.89$ & $462.73 \pm 34.16$ & $6.84 \pm 0.40$ & $4.48 \pm 0.27$ \\
\hline & Control & $7.71 \pm 0.02$ & $2882.28 \pm 45.45$ & $2784.93 \pm 50.79$ & $1259.10 \pm 57.47$ & $3.26 \pm 0.13$ & $2.14 \pm 0.08$ \\
$\mathrm{pH}^{-0.4}$ & CAF & $7.68 \pm 0.04$ & $2850.85 \pm 21.06$ & $2767.20 \pm 29.31$ & $1358.48 \pm 128.82$ & $3.09 \pm 0.26$ & $2.03 \pm 0.17$ \\
& DFC & $7.70 \pm 0.03$ & $2781.33 \pm 21.18$ & $2692.54 \pm 13.73$ & $1257.67 \pm 100.92$ & $3.15 \pm 0.24$ & $2.06 \pm 0.16$ \\
& PFOS & $7.69 \pm 0.03$ & $2813.03 \pm 49.36$ & $2727.18 \pm 50.17$ & $1283.96 \pm 96.75$ & $3.10 \pm 0.23$ & $2.03 \pm 0.16$ \\
& MIX & $7.70 \pm 0.02$ & $2818.77 \pm 18.41$ & $2725.22 \pm 22.82$ & $1274.35 \pm 69.08$ & $3.18 \pm 0.14$ & $2.09 \pm 0.09$ \\
\hline
\end{tabular}

\subsection{Spermotoxicity: Effects on Fertilization}

Spermotoxicity experiments were performed maintaining a constant sperm:egg ratio (1250:1) that allowed to obtain a percentage of fertilization, around $85 \%$ under control conditions [77]. A single pool of sperm and a single pool of eggs were set up with the gametes obtained from five males and five females. The same number of gametes from each individual was used so that the contribution of each parent was the same. To prepare the sperm pool, the gametes of each male were diluted in $10 \mathrm{~mL}$ of FSW to have a concentration of 108 sperm $/ \mathrm{mL}$. Multiwell plates ( 6 wells per plate of $6 \mathrm{~mL}$ each) were used for the exposure of sperm. A total of $3.99 \mathrm{~mL}$ of seawater (previously adjusted to the different experimental conditions) were poured into each well, and an aliquot of $10 \mu \mathrm{L}$ of sperm suspension was then added to have a final concentration of 250,000 sperm $/ \mathrm{mL}$. Sperm were then exposed for $30 \mathrm{~min}$, both in the absence and in the presence of the three chosen contaminants $(0.5 \mu \mathrm{g} / \mathrm{L})$, at two $\mathrm{pH}$ levels $\left(\mathrm{pH}^{\mathrm{Amb}}\right.$ and $\left.\mathrm{pH}^{-0.4}\right)$ for a total of eight experimental conditions. Three experimental replicates were set up for each condition. After $30 \mathrm{~min}, 100 \mu \mathrm{L}$ aliquots of the egg pool were added to have a final quantity of $800 \mathrm{eggs}$ in each well. Five minutes and $35 \mathrm{~min}$ after adding the eggs, the samples were fixed with the neutralized formalin solution. The success of fertilization was determined by verifying the presence or absence of the fertilization membrane in a subsample of 100 eggs per experimental replicate.

\subsection{Spermotoxicity: Effects on the Motility Parameters of Sperm}

Sperm from nine males were used to evaluate the effects of seawater $\mathrm{pH}$ and contaminants on sperm motility (percentage of motile sperm in the sample) and sperm velocity. During each test, sperm from a single male was exposed for a total of $30 \mathrm{~min}$ to two $\mathrm{pH}$ levels $\left(\mathrm{pH}^{\mathrm{Amb}}\right.$ and $\left.\mathrm{pH}^{-0.4}\right)$, both in the absence and in the presence of the three contaminants $(0.5 \mu \mathrm{g} / \mathrm{L})$, used both individually and in the mixture. For the exposure of sperm, the same plates described above for the fertilization tests and the same sperm concentration $(250,000 \mathrm{sperm} / \mathrm{mL}, 4 \mathrm{~mL}$ per well) were used. At 5, 15, and $30 \mathrm{~min}$ from the addition of the sperm to each well, an aliquot of sperm suspension was taken from each experimental condition and placed on a multiwell slide (MP Biomedicals, Aurora, OH, USA) pretreated with polyvinyl alcohol 1\% (Sigma-Aldrich, Milan, Italy) to prevent sperm from sticking 
to the slide, and was then covered with a coverslip. Sperm cells were then filmed under an optical microscope (Leica DM 750) provided with a Sony CCD camera (XC-ST50) and connected to a computer equipped with the Pinnacle Studio 15 program (Corel Corporation). The videos obtained were then analyzed with the CEROS sperm tracker (Hamilton Thorne Research, Beverly, MA, USA). The parameters calculated with the CASA system (Computer Assisted Sperm Analysis) were: (i) VCL (Curvilinear Velocity): it is based on the actual path taken by the sperm head and is measured in $\mu \mathrm{m} / \mathrm{s}$ and (ii) Motility: percentage of motile sperm in the sample. The above-mentioned observation times (5, 15, and $30 \mathrm{~min})$ were chosen following observations made during previous trials.

\subsection{Statistical Analyses}

The Permutational Analysis of Variance (PERMANOVA) with 9999 permutations, through the PERMANOVA+ program (PRIMER-E Ltd., Luton, UK) was used for the statistical analysis of the fertilization percentages. Sperm velocity and motility were analyzed using the statistical software PASW v.18.0 (SPSS Inc., Chicago, IL, USA). Before proceeding with the analysis, the normality of the data was verified (Kolmogorov-Smirnov test, $p>0.05$ ). Linear Mixed Models (LMM) were used to test the combined effects of $\mathrm{pH}$, time, and contaminants. To this end, $\mathrm{pH}$, contaminants, time, and their interactions were indicated as fixed factors in the models, while the sea urchin identity was entered as a random factor. The null hypotheses tested for fertilization success, as well as sperm VCL and motility, were: toward time (i) for each $\mathrm{pH}$ tested, no significant differences exist among treatments (Control, CAF, DCF, and PFOS, plus their mixture for sperm VCL and motility); and (ii) for each treatment tested, no significant differences exist among $\mathrm{pH}$ levels (Amb and -0.4 ). Statistical significance was set at $p<0.05$. In PERMANOVA, if the number of unique values from permutations was too low, $p$-values were calculated using the Monte Carlo procedure.

\section{Results}

Results of the PERMANOVA analysis and the LMM analysis are reported in Table 2. Significant effects of $\mathrm{pH}$ on the overall performance of the sperm of P. lividus were detected during both experiments. A significant effect of time of exposure and its interaction with $\mathrm{pH}$ was observed for sperm velocity (VCL).

Table 2. Permutational multivariate analysis of variance (PERMANOVA) and linear mixed model (LMM) results. For PERMANOVA, Pseudo-F values (indicated as F) and Monte Carlo $p$-values for percentage of fertilized eggs of $P$. lividus detected 5 and 35 min postfertilization at two $\mathrm{pH}$ levels $\left(\mathrm{pH}^{\mathrm{Amb}}\right.$ and $\left.\mathrm{pH}^{-0.4}\right)$, in absence or presence of $0.50 \mu \mathrm{g} / \mathrm{L}$ of caffeine, diclofenac, or PFOS. For LMM, F values and $p$-values for sperm velocity (VCL) and sperm motility (percentage of motile sperm in sample) of $P$. lividus, detected 5, 15, and $30 \mathrm{~min}$ post-sperm-activation at two $\mathrm{pH}$ levels (pH $\mathrm{pmb}^{\mathrm{Amb}}$ and $\left.\mathrm{pH}^{-0.4}\right)$, in absence or in presence of $0.50 \mu \mathrm{g} / \mathrm{L}$ of caffeine, diclofenac, PFOS or their mixture. Significant results are in bold.

\begin{tabular}{|c|c|c|c|}
\hline Factors & $\%$ of Fertilized Eggs (PERMANOVA) & VCL (LMM) & \% Motile Sperms (LMM) \\
\hline $\mathrm{pH}$ & $\begin{array}{c}\mathrm{F}_{(1,95)}=789.890 \\
p(\mathrm{MC})<0.001\end{array}$ & $\begin{array}{c}\mathrm{F}_{(1,204.0)}=4.288 \\
p=0.040\end{array}$ & $\begin{array}{c}\mathrm{F}_{(1,205.0)}=7.232 \\
p=0.008\end{array}$ \\
\hline $\begin{array}{l}\text { Contaminant } \\
\text { (Cont) }\end{array}$ & $\begin{array}{l}\mathrm{F}_{(3,95)}=0.731 \\
p(\mathrm{MC})=0.531\end{array}$ & $\begin{array}{c}\mathrm{F}_{(4,204.4)}=0.587 \\
p=0.673\end{array}$ & $\begin{array}{c}\mathrm{F}_{(4,205.5)}=0.699 \\
p=0.593\end{array}$ \\
\hline Time & $\begin{array}{l}\mathrm{F}_{(1,95)}=0.558 \\
p(\mathrm{MC})=0.073\end{array}$ & $\begin{array}{c}\mathrm{F}_{(2,204.5)}=32.982 \\
p<0.001\end{array}$ & $\begin{array}{c}\mathrm{F}_{(2,205.3)}=2.690 \\
p=0.070\end{array}$ \\
\hline $\mathrm{pH} x$ Cont & $\begin{array}{l}\mathrm{F}_{(3,95)}=0.394 \\
p(\mathrm{MC})=0.755\end{array}$ & $\begin{array}{c}\mathrm{F}_{(4,204.0)}=0.518 \\
p=0.722\end{array}$ & $\begin{array}{c}\mathrm{F}_{(4,205.0)}=0.933 \\
p=0.446\end{array}$ \\
\hline
\end{tabular}


Table 2. Cont.

\begin{tabular}{cccc}
\hline Factors & \% of Fertilized Eggs (PERMANOVA) & VCL (LMM) & \% Motile Sperms (LMM) \\
\hline \multirow{2}{*}{ pH $x$ Time } & $\mathrm{F}_{(1,95)}=0.483$ & $\mathrm{~F}_{(2,204.0)}=4.689$ & $p=0.010$ \\
& $p(\mathrm{MC})=0.127$ & $\mathrm{~F}_{(2,205.0)}=0.949$ & $p=0.389$ \\
Cont $x$ Time & $\mathrm{F}_{(3,95)}=0.251$ & $\mathrm{~F}_{(8,204.1)}=0.962$ & $\mathrm{~F}_{(8,205.0)}=0.887$ \\
& $p(\mathrm{MC})=0.860$ & $p=0.467$ & $p=0.528$ \\
$\mathrm{pH} x$ Cont $x$ Time & $\mathrm{F}_{(3,95)}=0.669$ & $\mathrm{~F}_{(8,204.0)}=0.922$ & $\mathrm{~F}_{(8,205.0)}=1.384$ \\
& $p(\mathrm{MC})=0.573$ & $p=0.499$ & $p=0.205$ \\
\hline
\end{tabular}

\subsection{Effects on Fertilization}

The obtained results showed a significant effect of $\mathrm{pH}$ on the percentage of fertilized eggs, while no effect of time, contaminants, or the interaction of the tested factors was found (Table 2). The average percentage of fertilized eggs was always lower than $50 \%$ when sperm were previously exposed to $\mathrm{pH}^{-0.4}$, whereas it was always higher than $70 \%$ when sperm were kept at $\mathrm{pH}^{\mathrm{Amb}}$ (Figure 1). Both in the absence and the presence of the tested contaminants, as confirmed by the PERMANOVA, there were no differences among treatments at both $\mathrm{pH}$ levels. Furthermore, the same trend of response was found at both $5 \mathrm{~min}$ and $35 \mathrm{~min}$ after fertilization at all the experimental conditions (Figure 1).

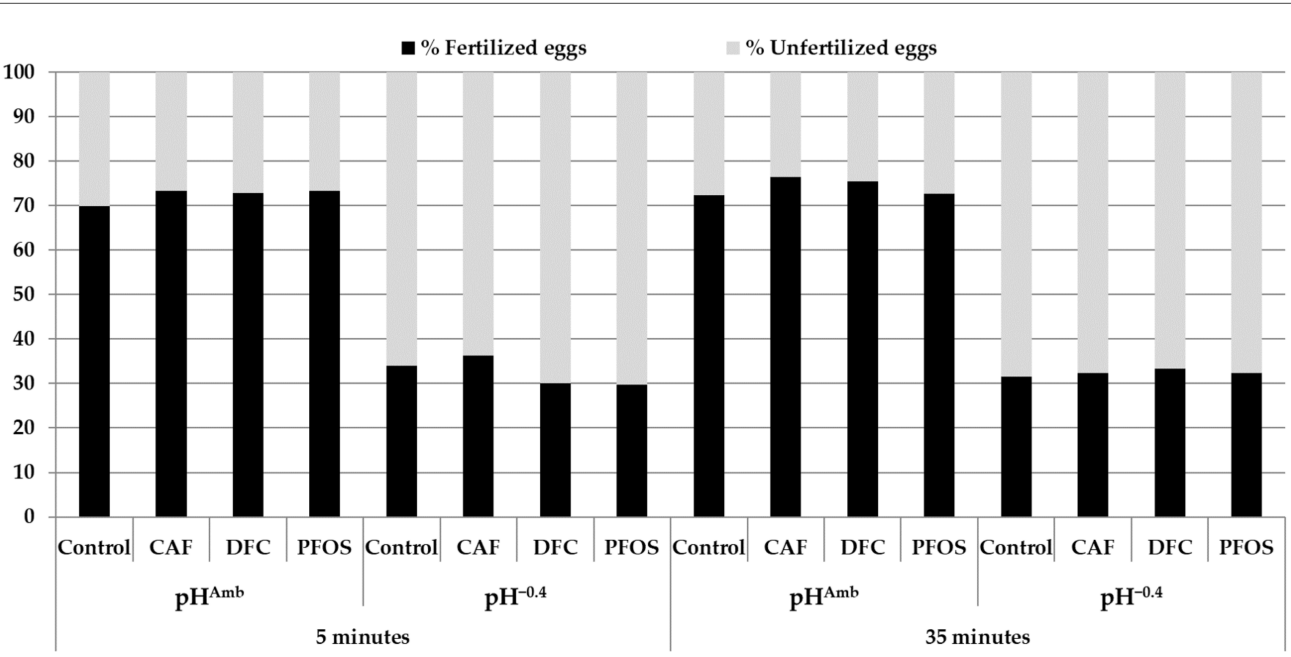

Figure 1. Percentage of fertilized eggs at 5 and $30 \mathrm{~min}$ postfertilization. On the $x$ axis, exposure conditions are shown. $\mathrm{pH}^{\mathrm{Amb}}=\mathrm{pH} 8.1,=\mathrm{pH} 7.7, \mathrm{CAF}=$ caffeine, $\mathrm{DFC}=$ diclofenac, $\mathrm{PFOS}=$ perfluorooctane sulfonate, $\mathrm{MIX}=$ mixture.

\subsection{Effects on Sperm Velocity and Motility}

The sperm VCL was negatively influenced by the reduction in $\mathrm{pH}$, while no significant effect of the contaminants was observed, either singularly or in mixture. Furthermore, no significant interaction was found between the contaminants and the other tested factors (Table 2). The results obtained also highlighted a significant effect of the exposure time (Table 2), with significant reductions in speed between $5 \mathrm{~min}$ and $30 \mathrm{~min}$ from sperm activation at both $\mathrm{pH}^{\mathrm{Amb}}$ and $\mathrm{pH}^{-0.4}$. A significant interaction emerged between $\mathrm{pH}$ and exposure time (Table 2, Figure 2).

Removing the effect of the contaminants from the analysis, a significant difference between $\mathrm{pHAmb}$ and $\mathrm{pH}-0.4$ was highlighted by LMM after 5 min postactivation, while after 15 and $30 \mathrm{~min}$ no difference in speed between the two $\mathrm{pH}$ levels was observed (Figure 3). In particular, compared to that of sperm activated at pHAmb, in those exposed to $\mathrm{pH}^{-0.4}$, there was a reduction in speed of $6 \%$ (equal to $20 \mu \mathrm{m} / \mathrm{s}$ ). 


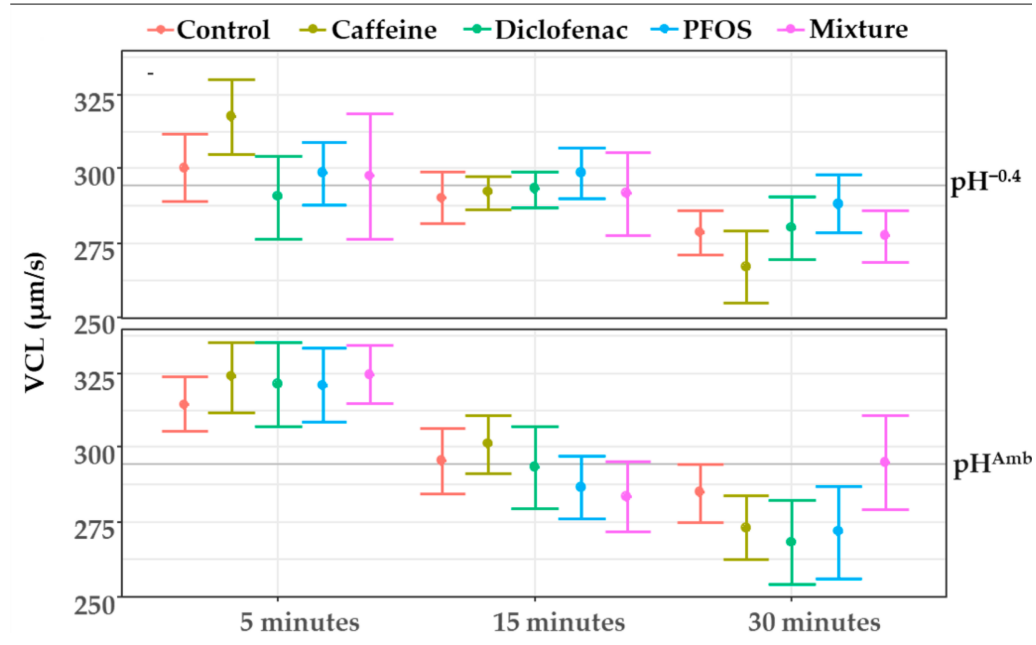

Figure 2. Sperm velocity (VCL) measured after 5, 15, and $30 \mathrm{~min}$ from activation at both $\mathrm{pH}^{\mathrm{Amb}}$ $\left(\mathrm{pH}\right.$ 8.1) and $\mathrm{pH}^{-0.4}(\mathrm{pH}$ 7.7) in absence or presence of contaminants. Values are means \pm SE. Horizontal line represents sample average.

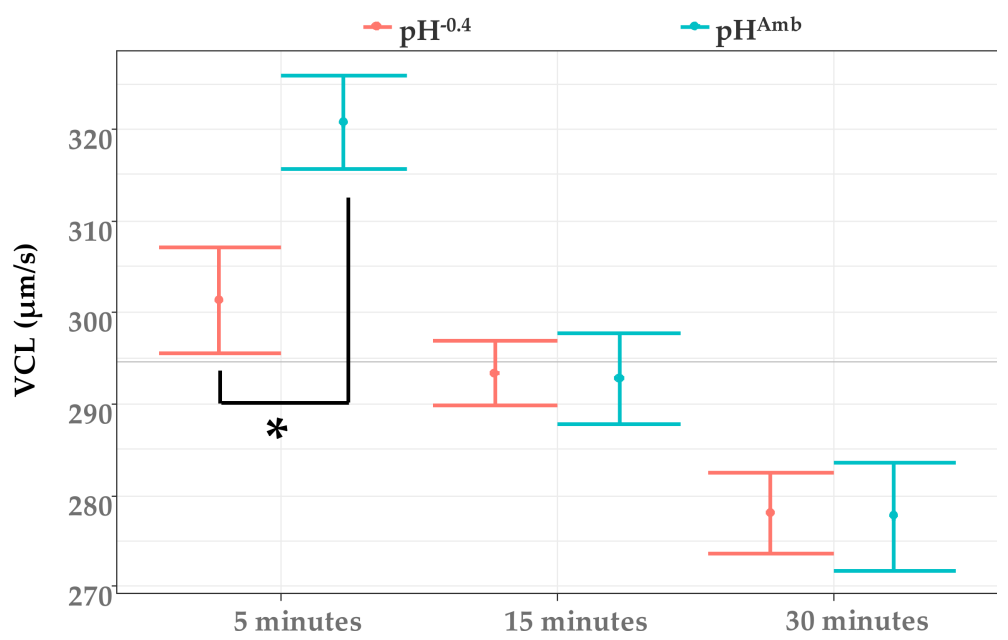

Figure 3. Sperm velocity (VCL) after 5, 15, and $30 \mathrm{~min}$ from activation at both $\mathrm{pH}^{\mathrm{Amb}}$ (pH 8.1) and $\mathrm{pH}^{-0.4}$ ( $\mathrm{pH}$ 7.7). Mean values $( \pm \mathrm{SE})$ from all treatments at same $\mathrm{pH}$ are reported. Horizontal line represents sample average. Asterisk denotes a significant difference between $\mathrm{pH}$ treatments at same time point $(p<0.05)$.

Sperm motility was significantly affected by $\mathrm{pH}$ (Table 2) with sperm being on average less motile in the $\mathrm{pH}^{-0.4}$ condition (Figure 4).

When considering only the effects of time and $\mathrm{pH}$, the LMM showed a significant difference among sperm kept at different $\mathrm{pH}$ for $5 \mathrm{~min}$ after activation (Figure 5). Also in this case, after 15 and $30 \mathrm{~min}$ the difference in the percentage of motile sperm exposed at the two $\mathrm{pH}$ levels tended to disappear (Figure 5). In particular, compared to that of sperm activated at $\mathrm{pH}^{\mathrm{Amb}}$, in those exposed to $\mathrm{pH}^{-0.4}$ a $9 \%$ reduction in the number of motile sperm was observed. 


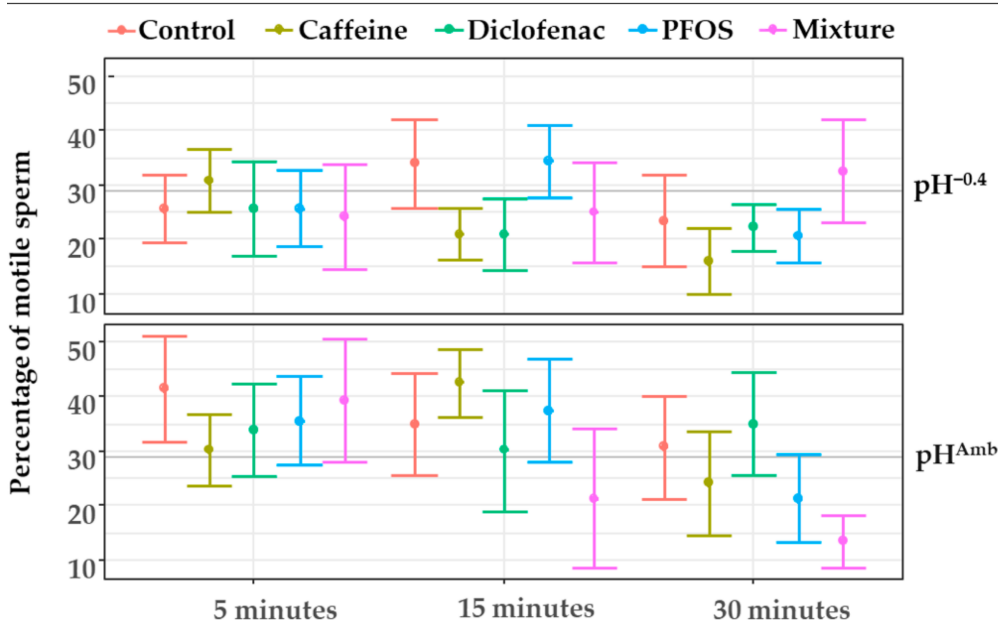

Figure 4. Sperm motility measured after 5, 15, and $30 \mathrm{~min}$ from activation at both $\mathrm{pH}^{\mathrm{Amb}}(\mathrm{pH} 8.1)$ and $\mathrm{pH}^{-0.4}(\mathrm{pH} 7.7)$ in absence or presence of contaminants. Values are means $\pm \mathrm{SE}$. Horizontal line represents sample average.

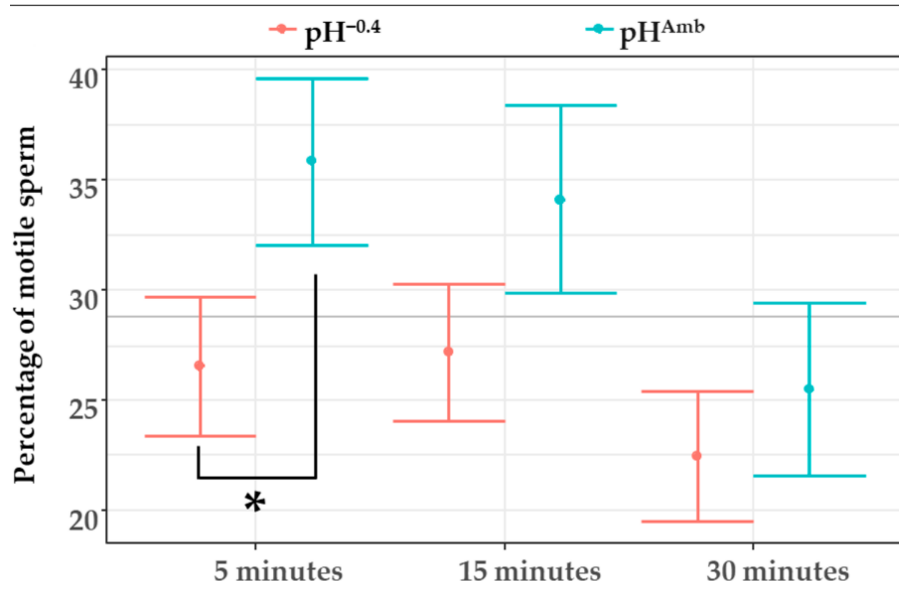

Figure 5. Sperm motility (percentage of motile sperm in sample) after 5, 15, and 30 min from activation at both $\mathrm{pH}^{\mathrm{Amb}}(\mathrm{pH} 8.1)$ and $\mathrm{pH}^{-0.4}(\mathrm{pH}$ 7.7). Mean values $( \pm \mathrm{SE})$ from all treatments at same $\mathrm{pH}$ are reported. Horizontal line represents sample average. Asterisk denotes a significant difference between $\mathrm{pH}$ treatments at same time point $(p<0.05)$.

\section{Discussion}

In our experiment, we demonstrated that water acidification strongly affects the key aspects of reproduction in P. lividus. Both sperm quality variables (velocity and motility) and fertilization success decreased after a short period of incubation in a low $\mathrm{pH}$ medium. Interestingly, none of the contaminants had a comparable effect, pointing to OA as the main threat to sea urchins, at least in our laboratory conditions. The growing interest in understanding the influence that OA could exert on marine organisms led to the development of an ever-expanding research sector [78]. Numerous studies demonstrated that the early stages of the life cycle of many marine organisms are the most susceptible to significant and persistent alterations of environmental parameters such as $\mathrm{pH}$, temperature, or salinity [48]. Particularly in coastal environments, organisms can also be exposed to a wide range of anthropogenic compounds that reach rivers and marine systems when they are not adequately removed during wastewater depuration processes [79]. The combined action of these stressors could especially affect those organisms that release their gametes into the water column, where fertilization takes place, and that develop calcareous structures already in the first larval stages, both characteristics that make them particularly susceptible to $\mathrm{OA}[2,48]$. To understand the effects of the natural conditions in which many marine 
species live or could live in possible scenarios of climate change, it is useful to investigate not only the consequences of $\mathrm{pH}$ variations, as indicated by predictive models, but also how these environmental changes can act on marine organisms when combined with the presence of emerging contaminants. Thus, in this study, we evaluated the combined effects of reduced $\mathrm{pH}$ and three contaminants (caffeine, diclofenac, PFOS), individually and in a mixture, on the first life stages of the sea urchin P. lividus. The results obtained showed that a 30' pre-exposure of the sperm to a variation of $0.4 \mathrm{pH}$ units (from $\mathrm{pH} 8.1$ to $\mathrm{pH}$ 7.7) caused a significant decrease in the percentage of fertilized eggs in P. lividus. At both observation times (after 5 and $35 \mathrm{~min}$ from the contact between sperm and eggs), with all contaminants, at $\mathrm{pH}^{\mathrm{Amb}}$ the fertilization percentage was higher than $70 \%$, while at $\mathrm{pH}^{-0.4}$ the average percentage was reduced by about $38 \%$. Previous studies showed that fertilization in echinoderms is, in general, negatively affected by OA but usually the adverse effects were only seen below $\mathrm{pH} 7.7$ [80-85]. In a recent study, Smith et al. [86] found no difference in the $\%$ of fertilization success when sperm were activated at reduced $\mathrm{pH}$ levels (7.90 and 7.77) and were compared with the controls (8.07) in two sea urchin species, Lytechinus pictus and Heliocidaris erythrogramma. In our study, the reduction in the percentage of fertilized eggs between the $\mathrm{pH}^{\mathrm{Amb}}$ conditions and those at $\mathrm{pH}^{-0.4}$ was almost $40 \%$. When compared with the few data available for other species, our findings suggested a greater sensitivity of $P$. lividus to OA concerning fertilization. We note, however, that in our study P. lividus sperm were pre-exposed to the experimental conditions for $30 \mathrm{~min}$ before fertilization, whereas in other studies from the literature the gametes of both sexes were subjected to the various experimental conditions at the same time. This suggested that male gametes could be particularly prone to the negative effects of acidification. Our results did not highlight significant effects of the three contaminants at the investigated concentrations, nor of their interaction with reduced $\mathrm{pH}$. Similarly, in another study conducted on sperm of $P$. lividus, $1 \mathrm{~h}$ of exposure to caffeine concentrations ranging from 0.01 to $15 \mu \mathrm{g} / \mathrm{L}$ led to no significant change in fertilization rate. Conversely, at concentrations between $10^{6}$ and $50^{6} \mu \mathrm{g} / \mathrm{L}$ the fertilization rate was 80 to $100 \%$ lower than that observed in controls [87]. Although there are no data in the literature on the effects of diclofenac and PFOS on the sea urchin fertilization process, a good amount of information is available regarding the effects of many environmental contaminants in different species of echinoids. For example, in Arbacia punctulata fertilization in the presence of a mixture of lindane (a pesticide) and phenanthrene (a polycyclic aromatic hydrocarbon) was reduced by $30 \%$ at a concentration of $4.76 \mu \mathrm{mol} / \mathrm{L}$ and by $100 \%$ at $19.06 \mu \mathrm{mol} / \mathrm{L}$ [88]. In another study on P. lividus, one hour of sperm pre-exposure to three metal compounds in environmentally relevant concentrations $\left(\mathrm{CdCl}_{2} 0.18 \mu \mathrm{g} / \mathrm{L}, \mathrm{CuSO}_{4} 0.16 \mu \mathrm{g} / \mathrm{L}\right.$ and TBTCl $\left.0.32 \mu \mathrm{g} / \mathrm{L}\right)$ did not cause significant reductions in the fertilization ability, while at concentrations a thousand times higher the average fertilization percentage was about 50\% compared to controls [89]. The authors suggested that the reduced percentage of fertilized eggs observed was due to a toxic effect of heavy metals on sperm, which might have involved an alteration in their motility. About the negative effects of $\mathrm{pH}$ reduction on fertilization, some authors $[84,90]$ suggested that the increase in $\mathrm{pCO}_{2}$ of seawater had a narcoleptic effect on sperm, decreasing their respiration and thus their flagellar motility. In this study, we tested this hypothesis by exposing sperm of nine P. lividus males to two $\mathrm{pH}$ levels (8.1 and 7.7) for half an hour postactivation in the absence and the presence of the three selected contaminants, both individually and in a full mixture. The results obtained showed that a moderate reduction in $\mathrm{pH}$ had a significant effect on both the sperm swimming speed and the percentage of motile sperm. These differences were particularly pronounced after $5^{\prime}$ from activation. In particular, compared to sperm activated at $\mathrm{pH} 8.1$, in those exposed to acidification, a $6 \%$ reduction in the speed (equal to $20 \mu \mathrm{m} / \mathrm{s}$ ) and $9 \%$ in the number of motile sperm were observed. The $0-5^{\prime}$ time interval is important considering that in other species, under laboratory conditions, the majority of fertilization episodes happen within this time range [91], and despite optimal conditions, fertilization ability in P. lividus is maintained for longer [92]. In another marine invertebrate, the madrepora Acropora digitifera, Nakamura, and Morita [40] found that the percentage 
of motile spermatozoa decreased by $36.5 \%$ when comparing preindustrial levels of $\mathrm{pCO}_{2}$ $(300 \mathrm{ppm}=\mathrm{pH} 8.1)$ with those expected for the end of this century $(1000 \mathrm{ppm}=\mathrm{pH} 7.7)$. In contrast to our results, Smith et al. [86] found a significant increase in sperm motility at $\mathrm{pH} 7.7$ when compared to $\mathrm{pH} 8.07$ in the two sea urchin species Lytechinus pictus and Heliocidaris erythrogramma. Esposito et al. [33] in the two marine invertebrates Mytilus galloprovincialis and Ciona robusta, observed a reduction in sperm motility of $12.5 \%$ and $15.4 \%$, respectively, when comparing the controls exposed at $\mathrm{pH} 8.11$ and the treatments at $\mathrm{pH}$ 7.80. The performance of sperm, and therefore fertilization success, can be influenced also by the recognition of peptides present on the surface of the eggs or by other chemicals released into the water together with the eggs themselves [93-95]. In our experiments aimed at evaluating the ability of sperm to fertilize eggs, OA could have somehow altered the molecules present on the surface of the eggs or, given the pre-exposure, the ability of sperm to recognize the eggs in the media; thus, further affecting the success of fertilization. Similar to variations in environmental parameters, the presence of toxic substances in the medium in which sperm are released can cause damage to sperm cells, reducing their ability to move in the water column and to fertilize eggs, or increasing the possibility of transmission of genetic damage to the next generation [96]. For example, exposure of Mytilus edulis sperm to high copper levels (6300-208,000 $\mathrm{mg} / \mathrm{L}$ ) caused mitochondrial damage [97], while in the sea urchin Anthocidaris crassispina, cadmium concentrations greater than $5 \mathrm{mg} / \mathrm{L}$ produced cytoplasmic membrane alterations, mitochondrial damage, and flagellum rupture with dramatic effects on sperm swimming ability $[98,99]$. In our study, no negative effects on sperm motility following exposure to contaminants or a significant interaction between the lowering of $\mathrm{pH}$ and contaminants were highlighted. Overall, our results suggested that $\mathrm{pH}$ levels predicted to occur in the next future may impact the performance of sperm in the sea urchin P. lividus, thus posing a further threat to natural populations of this species that a relevant ecological role in coastal environments. However, further studies are needed to better understand the effect of $\mathrm{OA}$ in combination with emerging contaminants on marine species from different locations since it was recently demonstrated that not all the populations of $P$. lividus respond in the same way to future climate change scenarios [100].

Author Contributions: Conceptualization, M.M. and M.G.M.; methodology, M.M. and M.G.M.; data analysis, M.M., A.D., G.d.P., D.A., P.P., D.B. and M.G.M.; investigation, M.M., A.D. and G.d.P.; chemical analysis, P.P. and D.B.; writing-original draft preparation, M.M.; writing-review and editing, M.M., A.D., D.A. and M.G.M. All authors have read and agreed to the published version of the manuscript.

Funding: This research received no external funding.

Institutional Review Board Statement: Not applicable.

Informed Consent Statement: Not applicable.

Data Availability Statement: Data will be available upon request.

Acknowledgments: Special thanks are given to Andrea Sambo and Cristina Breggion for their valuable technical assistance during organisms' collection at the Umberto D'Ancona Hydrobiological Station. We also thank Andrea Pilastro for his assistance with sperm velocity analyses. We are grateful to the editor and the referees who provided thoughtful comments that greatly improved our manuscript.

Conflicts of Interest: The authors declare no conflict of interest.

\section{References}

1. Doney, S.C.; Schimel, D.S. Carbon and climate system coupling on timescales from the Precambrian to the Anthropocene. Annu. Rev. Environ. Resour. 2007, 32, 31-66. [CrossRef]

2. Doney, S.C.; Fabry, V.J.; Feely, R.A.; Kleypas, J.A. Ocean acidification: The other $\mathrm{CO}_{2}$ problem. Ann. Rev. Mar. Sci. $2009,1,169-192$. [CrossRef] [PubMed]

3. IPCC. IPCC Special Report on the Ocean and Cryosphere in a Changing Climate, Intergovernmental Panel on Climate Change; IPCC: Geneva, Switzerland, 2019. 
4. Sabine, C.L.; Feely, R.A.; Gruber, N.; Key, R.M.; Lee, K.; Bullister, J.L.; Wanninkhof, R.; Wong, C.S.; Wallace, D.W.R.; Tilbrook, B.; et al. The Oceanic Sink for Anthropogenic $\mathrm{CO}_{2}$. Science 2004, 305, 367-371. [CrossRef] [PubMed]

5. Caldeira, K.; Wickett, M.E. Ocean model predictions of chemistry changes from carbon dioxide emissions to the atmosphere and ocean. J. Geophys. Res. Oceans 2005, 110, C09S04. [CrossRef]

6. $\quad$ Raven, J.; Caldeira, K.; Elderfield, H.; Hoegh-Guldberg, O.; Liss, P.; Riebesell, U.; Shepherd, J.; Turley, C.; Watson, A. Ocean Acidification due to Increasing Atmospheric Carbon Dioxide; Policy Document; The Royal Society: London, UK, 2005.

7. Ripple, W.J.; Wolf, C.; Newsome, T.M.; Barnard, P.; Moomaw, W.R. World scientists' warning of a climate emergency. Bioscience 2019, 70, 8-12. [CrossRef]

8. Fabricius, K.E.; Langdon, C.; Uthicke, S.; Humphrey, C.; Noonan, S.; De'ath, G.; Okazaki, R.; Muehllehner, N.; Glas, M.S.; Lough, J.M. Losers and winners in coral reefs acclimatized to elevated carbon dioxide concentrations. Nat. Clim. Chang. 2011, 1, 29. [CrossRef]

9. Hall-Spencer, J.M.; Rodolfo-Metalpa, R.; Martin, S.; Ransome, E.; Fine, M.; Turner, S.M.; Rowley, S.J.; Tedesco, D.; Buia, M.C. Volcanic carbon dioxide vents show ecosystem effects of ocean acidification. Nature 2008, 454, 96-99. [CrossRef]

10. Kroeker, K.J.; Micheli, F.; Gambi, M.C.; Martz, T.R. Divergent ecosystem responses within a benthic marine community to ocean acidification. Proc. Natl. Acad. Sci. USA 2011, 108, 14515-14520. [CrossRef]

11. Kroeker, K.J.; Micheli, F.; Gambi, M.C. Ocean acidification causes ecosystem shifts via altered competitive interactions. Nat. Clim. Chang. 2013, 3, 156-159. [CrossRef]

12. Schiedek, D.; Sundelin, B.; Readman, J.W.; Macdonald, R.W. Interactions between climate change and contaminants. Mar. Pollut. Bull. 2007, 54, 1845-1856. [CrossRef]

13. Nikinmaa, M. Climate change and ocean acidification-interactions with aquatic toxicology. Aquat. Toxicol. 2013, 15, 365-372. [CrossRef]

14. Dahms, H.U. The grand challenges in marine pollution research. Front. Mar. Sci. 2014, 1, 9. [CrossRef]

15. Delorenzo, M.E. Impacts of climate change on the ecotoxicology of chemical contaminants in estuarine organisms. Curr. Zool. 2015, 61, 641-652. [CrossRef]

16. Fent, K.; Weston, A.A.; Caminada, D. Ecotoxicology of human pharmaceuticals. Aquat. Toxicol. 2006, 76, 122-159. [CrossRef] [PubMed]

17. Fekadu, S.; Alemayehu, E.; Dewil, R.; Van der Bruggen, B. Pharmaceuticals in freshwater aquatic environments: A comparison of the African and European challenge. Sci. Total Environ. 2019, 654, 324-337. [CrossRef] [PubMed]

18. Freitas, R.; Almeida, A.; Calisto, V.; Velez, C.; Moreira, A.; Schneider, R.J.; Esteves, V.I.; Wrona, F.J.; Figueira, E.; Soares, A.M.V.M. The impacts of pharmaceutical drugs under ocean acidification: New data on single and combined long-term effects of carbamazepine on Scrobicularia plana. Sci. Total Environ. 2016, 541, 977-985. [CrossRef]

19. Almeida, A.; Freitas, R.; Calisto, V.; Esteves, V.I.; Schneider, R.J.; Soares, A.M.V.M.; Figueira, E.; Campos, B.; Barata, C. Effects of carbamazepine and cetirizine under an ocean acidification scenario on the biochemical and transcriptome responses of the clam Ruditapes philippinarum. Environ. Pollut. 2018, 235, 857-868. [CrossRef] [PubMed]

20. Munari, M.; Chemello, G.; Finos, L.; Ingrosso, G.; Giani, M.; Marin, M.G. Coping with seawater acidification and the emerging contaminant diclofenac at the larval stage: A tale from the clam Ruditapes philippinarum. Chemosphere 2016, 160, 293-302. [CrossRef]

21. Munari, M.; Matozzo, V.; Gagné, F.; Chemello, G.; Riedl, V.; Finos, L.; Pastore, P.; Badocco, D.; Marin, M.G. Does exposure to reduced $\mathrm{pH}$ and diclofenac induce oxidative stress in marine bivalves? A comparative study with the mussel Mytilus galloprovincialis and the clam Ruditapes philippinarum. Environ. Pollut. 2018, 240, 925-937. [CrossRef]

22. Munari, M.; Matozzo, V.; Chemello, G.; Riedl, V.; Pastore, P.; Badocco, D.; Marin, M.G. Seawater acidification and emerging contaminants: A dangerous marriage for haemocytes of marine bivalves. Environ. Res. 2019, 175, 11-21. [CrossRef]

23. Munari, M.; Matozzo, V.; Benetello, G.; Riedl, V.; Pastore, P.; Badocco, D.; Marin, M.G. Exposure to Decreased pH and Caffeine Affects Hemocyte Parameters in the Mussel Mytilus galloprovincialis. J. Mar. Sci. Eng. 2020, 8, 238. [CrossRef]

24. Munari, M.; Matozzo, V.; Riedl, V.; Pastore, P.; Badocco, D.; Marin, M.G. EAT BREATHE EXCRETE REPEAT: Physiological Responses of the Mussel Mytilus galloprovincialis to Diclofenac and Ocean Acidification. J. Mar. Sci. Eng. 2020, 8, 907. [CrossRef]

25. Dorey, N.; Maboloc, E.; Chan, K.Y.K. Development of the sea urchin Heliocidaris crassispina from Hong Kong is robust to ocean acidification and copper contamination. Aquat. Toxicol. 2018, 205, 1-10. [CrossRef] [PubMed]

26. Da Silva Souza, L.; Pusceddu, F.H.; Cortez, F.S.; de Orte, M.R.; Seabra, A.A.; Cesar, A.; Ribeiro, D.A.; Del Valls Casillas, T.A.; Pereira, C.D.S. Harmful effects of cocaine byproduct in the reproduction of sea urchin in different ocean acidification scenarios. Chemosphere 2019, 236, 124284. [CrossRef] [PubMed]

27. Caetano, L.S.; Pereira, T.M.; Envangelista, J.D.; Cabral, D.S.; Carvalho Coppo, G.; de Souza, L.A.; Anderson, A.B.; Heringer, O.A.; Chippari-Gomes, A.R. Impact on fertility rate and embryo-larval development due to the association acidification, ocean warming and lead contamination of a sea urchin Echinometra lucunter (Echinodermata: Echinoidea). Bull. Environ. Contam. Toxicol. 2021, 106, 923-928. [CrossRef]

28. Lewis, C.; Clemow, K.; Holt, W.V. Metal contamination increases the sensitivity of larvae but not gametes to ocean acidification in the polychaete Pomatoceros lamarckii (Quatrefages). Mar. Biol. 2013, 160, 2089-2101. [CrossRef]

29. Campbell, A.L.; Mangan, S.; Ellis, R.P.; Lewis, C. Ocean acidification increases copper toxicity to the early life history stages of the polychaete Arenicola marina in artificial seawater. Environ. Sci. Technol. 2014, 48, 9745-9753. [CrossRef] 
30. De Marchi, L.; Pretti, C.; Chiellini, F.; Morelli, A.; Neto, V.; Soares, A.M.V.M.; Figueira, E.; Freitas, R. The influence of simulated global ocean acidification on the toxic effects of carbon nanoparticles on polychaetes. Sci. Total Environ. 2019, 666, 1178-1187. [CrossRef]

31. Havenhand, J.N.; Schlegel, P. Near-future levels of ocean acidification do not affect sperm motility and fertilization kinetics in the oyster Crassostrea gigas. Biogeosciences 2009, 6, 3009-3015. [CrossRef]

32. Shi, W.; Han, Y.; Guo, C.; Su, W.; Zhao, X.; Zha, S.; Wang, Y.; Liu, G. Ocean acidification increases the accumulation of titanium dioxide nanoparticles (nTiO2) in edible bivalve mollusks and poses a potential threat to seafood safety. Sci. Rep. 2019, 9, 3516. [CrossRef]

33. Esposito, M.C.; Boni, R.; Cuccaro, A.; Tosti, E.; Gallo, A. Sperm motility impairment in free spawning invertebrates under near-future level of ocean acidification: Uncovering the mechanism. Front. Mar. Sci. 2020, 6, 794. [CrossRef]

34. Caldwell, G.S.; Fitzer, S.; Gillespie, C.S.; Pickavance, G.; Turnbull, E.; Bentley, M.G. Ocean acidification takes sperm back in time. Invertebr. Reprod. Dev. 2011, 55, 217-221. [CrossRef]

35. Havenhand, J.N.; Buttler, F.R.; Thorndyke, M.C.; Williamson, J.E. Near-future levels of ocean acidification reduce fertilization success in a sea urchin. Curr. Biol. 2008, 18, R651. [CrossRef] [PubMed]

36. Schlegel, P.; Havenhand, J.N.; Gillings, M.R.; Williamson, J.E. Individual variability in reproductive success determines winners and losers under ocean acidification: A case study with sea urchins. PLoS ONE 2012, 7, e53118. [CrossRef] [PubMed]

37. Schlegel, P.; Binet, M.T.; Havenhand, J.N.; Doyle, C.J.; Williamson, J.E. Ocean acidification impacts on sperm mitochondrial membrane potential bring sperm swimming behaviour near its tipping point. J. Exp. Biol. 2015, 218, 1084-1090. [CrossRef]

38. Lenz, B.; Fogarty, N.D.; Figueiredo, J. Effects of ocean warming and acidification on fertilization success and early larval development in the green sea urchin Lytechinus variegatus. Mar. Poll. Bull. 2019, 141, 70-78. [CrossRef]

39. Morita, M.; Suwa, R.; Iguchi, A.; Nakamura, M.; Shimada, K.; Sakai, K.; Suzuki, A. Ocean acidification reduces sperm flagellar motility in broadcast spawning reef invertebrates. Zygote 2010, 18, 103-107. [CrossRef]

40. Nakamura, M.; Morita, M. Sperm motility of the scleractinian coral Acropora digitifera under preindustrial, current, and predicted ocean acidification regimes. Aquat Biol. 2012, 15, 299-302. [CrossRef]

41. Rossin., A.M.; Waller, R.G.; Stone, R.P. The effects of in-vitro pH decrease on the gametogenesis of the red tree coral, Primnoa pacifica. PLOS ONE 2019, 14, e0203976. [CrossRef]

42. Schlegel, P.; Havenhand, J.N.; Obadia, N.; Williamson, J.E. Sperm swimming in the polychaete Galeolaria caespitosa shows substantial interindividual variability in response to future ocean acidification. Mar. Pollut. Bull. 2014, 78, 213-217. [CrossRef]

43. Frommel, A.Y.; Stiebens, V.; Clemmesen, C.; Havenhand, J. Effect of ocean acidification on marine fish sperm (Baltic cod: Gadus morhua). Biogeosciences 2010, 7, 3915-3919. [CrossRef]

44. Lewis, C.; Ford, A.T. Infertility in male aquatic invertebrates: A review. Aquat. Toxicol. 2012, 120, 79-89. [CrossRef] [PubMed]

45. Dinnel, P.A.; Stober, Q.J. Application of the sea urchin sperm bioassay to sewage treatment efficiency and toxicity in marine waters. Mar. Environ. Res. 1987, 21, 121-133. [CrossRef]

46. Byrne, M.; Prowse, T.; Sewell, M.A.; Dworjanyn, S.A.; Williamson, J.E.; Vaïtilingon, D. Maternal provisioning for larvae and larval provisioning for juveniles in the toxopneustid sea urchin Tripneustes gratilla. Mar. Biol. 2008, 155, 473-482. [CrossRef]

47. Byrne, M.; Soars, N.A.; Ho, M.A.; Wong, E.; Mc Elroy, D.; Selvakumaraswamy, P.; Dworjanyn, S.A.; Davis, A.R. Fertilization in a suite of coastal marine invertebrates from SE Australia is robust to near-future ocean warming and acidification. Mar. Biol. 2010, 157, 2061-2069. [CrossRef]

48. Byrne, M. Global change ecotoxicology: Identification of early life history bottlenecks in marine invertebrates, variable species responses and variable experimental approaches. Mar. Environ. Res. 2012, 76, 3-15. [CrossRef]

49. Fitzpatrick, J.L.; Nadella, S.; Bucking, C.; Balshine, S.; Wood, C.M. The relative sensitivity of sperm, eggs and embryos to copper in the blue mussel (Mytilus trossulus). Comp. Biochem. Physiol. C Toxicol. 2008, 147, 441-449. [CrossRef]

50. Bonaventura, R.; Costa, A.; Pinsino, A.; Russo, R.; Zito, F.; Matranga, V. Echinoderms: Model organisms for marine environmental monitoring and development of new emerging technologies. In Marine Research at CNR; Department of Earth and Environment, National Research Council of Italy: Rome, Italy, 2011; pp. 1967-1978.

51. Ruocco, N.; Bertocci, I.; Munari, M.; Musco, L.; Caramiello, D.; Danovaro, R.; Zupo, V.; Costantini, M. Morphological and molecular responses of the sea urchin Paracentrotus lividus to highly contaminated marine sediments: The case study of BagnoliCoroglio brownfield (Mediterranean Sea). Mar. Environ. Res. 2020, 154, 104865. [CrossRef]

52. Limatola, N.; Bertocci, I.; Chun, J.T.; Musco, L.; Munari, M.; Caramiello, D.; Danovaro, R.; Santella, L. Oxygen supersaturation mitigates the impact of the regime of contaminated sediment reworking on sea urchin fertilization process. Mar. Environ. Res. 2020, 158, 104951. [CrossRef]

53. Chiarore, A.; Musco, L.; Bertocci, I.; Gallo, A.; Cannavacciuolo, A.; Mutalipassi, M.; Caramiello, D.; Giomi, F.; Fusi, M.; Danovaro, R.; et al. Sea urchin chronicles. The effect of oxygen super-saturation and marine polluted sediments from Bagnoli-Coroglio Bay on different life stages of the sea urchin Paracentrotus lividus. Mar. Environ. Res. 2020, 159, 104967. [CrossRef]

54. Sala, E.; Zabala, M. Fish predation and the structure of the sea urchin Paracentrotus lividus populations in the NW Mediterranean. Mar. Ecol. Prog. Ser. 1996, 140, 71-81. [CrossRef]

55. Guidetti, P.; Fraschetti, S.; Terlizzi, A.; Boero, F. Distribution patterns of seaurchins and barrens in shallow Mediterranean rocky reefs impacted by the illegal fishery of the rock-boring mollusc Lithophaga lithophaga. Mar. Biol. 2003, 143, 1135-1142. [CrossRef] 
56. Guidetti, P. Consumers of sea urchins, Paracentrotus lividus and Arbacia lixula, in shallow Mediterranean rocky reefs. Helgol. Mar. Res. 2004, 58, 110. [CrossRef]

57. Bertocci, I.; Dell'Anno, A.; Musco, L.; Gambi, C.; Saggiomo, V.; Cannavacciuolo, M.; Lo Martire, M.; Passarelli, A.; Zazo, G.; Danovaro, R. Multiple human pressures in coastal habitats: Variation of meiofaunal assemblages associated with sewage discharge in a post-industrial area. Sci. Total Environ. 2019, 655, 1218-1231. [CrossRef]

58. Gianguzza, P.; Badalamenti, F.; Gianguzza, F.; Bonaviri, C.; Riggio, S. The operational sex ratio of the sea urchin Paracentrotus lividus populations: The case of the Mediterranean marine protected area of Ustica Island (Tyrrhenian Sea, Italy). Mar. Ecol. 2009, 30, 125-132. [CrossRef]

59. Spirlet, C.; Grosjean, P.; Jangoux, M. Reproductive cycle of the echinoid Paracentrotus lividus: Analysis by means of the maturity index. Invertebr. Reprod. Dev. 1998, 34, 69-81. [CrossRef]

60. Buser, H.R.; Poiger, T.; Muller, M.D. Occurrence and fate of the pharmaceutical drug diclofenac in surface waters: Rapid photodegradation in a lake. Environ. Sci. Technol. 1998, 32, 3449-3456. [CrossRef]

61. Ternes, T.A. Occurrence of drugs in german sewage treatment plants and rivers. Water Res. 1998, 32, 3245-3260. [CrossRef]

62. Metcalfe, C.D.; Miao, X.S.; Koenig, B.G.; Struger, J. Distribution of acidic and neutral drugs in surface waters near sewage treatment plants in the lower great lakes, Canada. Environ. Toxicol. Chem. 2003, 22, 2881-2889. [CrossRef]

63. Ashton, D.; Hilton, M.; Thomas, K.V. Investigating the environmental transport of human pharmaceuticals to streams in the United Kingdom. Sci. Total Environ. 2004, 333, 167-184. [CrossRef]

64. Weigel, S.; Kuhlmann, J.; Hünerfuss, H. Drugs and personal care products as ubiquitous pollutants: Occurrence and distribution of chlorfibric acid, caffeine and deet in the North Sea. Sci. Total Environ. 2002, 295, 131-141. [CrossRef]

65. Scheytt, T.; Mersmann, P.; Lindstadt, R.; Heberer, T. Determination of sorption coefficients of pharmaceutically active substances carbamazepine, diclofenac, and ibuprofen, in sandy sediments. Chemosphere 2005, 60, 245-253. [CrossRef] [PubMed]

66. Rodrìguez-Navas, C.; Björklund, E.; Bak, S.A.; Hansen, M.; Krogh, K.A.; Maya, F.; Forteza, R.; Cerdà, V. Pollution pathways of pharmaceutical residues in the aquatic environment on the island of Mallorca, Spain. Arch. Environ. Contam. Toxicol. 2013, 65, 56-66. [CrossRef]

67. Nawrot, P.; Jordan, S.; Eastwood, J.; Rotstein, J.; Hugenholtz, A.; Feeley, M. Effects of caffeine on human health. Food Addit. Contam. 2003, 20, 1-30. [CrossRef]

68. Fulgoni, V.L.; Keast, D.R.; Lieberman, H.R. Trends in intake and sources of ca_eine in the diets of US adults: 2001-20101-4. Am. J. Clin. Nutr. 2015, 101, 1081-1087. [CrossRef]

69. Siegener, R.; Chen, R.F. Caffeine in Boston Harbor seawater. Mar. Pollut. Bull. 2002, 44, 383-387. [CrossRef]

70. Munschy, C.; Bely, N.; Pollono, C.; Aminot, Y. Perfluoroalkyl substances (PFASs) in the marine environment: Spatial distribution and temporal profile shifts in shellfish from French coasts. Chemosphere 2019, 228, 640-648.

71. Martín, J.; Hidalgo, F.; García-Corcoles, M.T.; Ibáñez-Yuste, A.J.; Alonso, E.; Vilchez, J.L.; Zafra-Gòmez, A. Bioaccumulation of perfluoroalkyl substances in marine echinoderms: Results of laboratory-scale experiments with Holothuria tubulosa Gmelin, 1791 Chemosphere 2019, 215, 261-271. [CrossRef]

72. Sciancalepore, G.; Pietroluongo, G.; Centelleghe, C.; Milan, M.; Bonato, M.; Corazzola, G.; Mazzariol, S. Evaluation of per- and poly-fluorinated alkyl substances (PFAS) in livers of bottlenose dolphins (Tursiops truncatus) found stranded along the northern Adriatic Sea. Environ. Poll. 2021, 291, 118186. [CrossRef]

73. EU. Directive 2006/122/EC of the European Parliament and of the Council of 12 December 2006 Amending for the 30th Time Council Directive 76/769/EEC on the Approximation of the Laws, Regulations and Administrative Provisions of the Member States Relating to Restrictions on the Marketing and Use of Certain Dangerous Substances and Preparations (Perfluorooctane Sulfonates). 2006. Available online: https:/ / eur-lex.europa.eu/legal-content/EN/TXT/?uri=celex\%3A32006L0122 (accessed on 29 December 2021).

74. UNEP. Stockholm convention on persistent organic pollutants (POPs). In The 16 New POPs, an Introduction to the Chemicals Added to the Stockholm Convention as Persisitent Organci Pollutants by the Conference of the Parties, June 2017; InforMEA: Nairobi, Kenya, 2017; p. 25. Available online: www.pops.int (accessed on 29 December 2021).

75. Brooke, D.; Footitt, A.; Nwaogu, T.A. Environmental Risk Evaluation Report: Perfluorooctanesulphonate (PFOS); Environment Agency: Bristol, UK, 2004; ISBN 978-1-84911-124-9.

76. Cannavacciuolo, A.; Chiarore, A.; Munari, M. A cold bath for a formalin-free laboratory: Alternative fixative methods in early developmental stages of the sea urchin Paracentrotus lividus (Lamarck, 1816). ISJ 2020, 18, 11-18.

77. Moschino, V.; Marin, M.G. Spermiotoxicity and embriotoxicity of triphenylthin in the sea urchin Paracentrotus lividus. Appl. Organomet. Chem. 2002, 16, 175-181. [CrossRef]

78. Linares, C.; Vidal, M.; Canals, M.; Kersting, D.K.; Amblas, D.; Aspillaga, E.; Cebrián, E.; Delgado-Huertas, A.; Díaz, D.; Garrabou, J.; et al. Persistent natural acidification drives major distribution shifts in marine benthic ecosystems. Proc. Biol. Sci. 2015, 282, 20150587. [CrossRef] [PubMed]

79. Murray, K.E.; Thomas, S.M.; Bodour, A.A. Prioritizing research for trace pollutants and emerging contaminants in the freshwater environment. Environ. Poll. 2010, 158, 3462-3471. [CrossRef] [PubMed]

80. Rupp, J.H. Effects of temperature on fertilization and early cleavage of some tropical echinoderms, with emphasis on Echinometra mathaei. Mar. Biol. 1973, 23, 183-189. [CrossRef] 
81. Bay, S.; Burgess, R.; Nacci, D. Environmental Toxicology and Risk Assessment; American Society for Testing and Materials: Philadelphia, PA, USA, 1993; pp. 281-302.

82. Kurihara, H.; Shirayama, Y. Effects of increased atmospheric $\mathrm{CO}_{2}$ on sea urchin early development. Mar. Ecol. Progr. Ser. 2004, 274, 161-169. [CrossRef]

83. Carr, R.S.; Biedenbach, J.M.; Nipper, M. Influence of potentially confounding factors on sea urchin porewater toxicity tests. Arch. Environ. Con. Tox. 2006, 51, 573-579. [CrossRef]

84. Ericson, J.A.; Lamare, M.D.; Morley, S.A.; Barker, M.F. The response of two ecologically important Antarctic invertebrates (Sterechinus neumayeri and Parborlasia corrugatus) to reduced seawater $\mathrm{pH}$ : Effects on fertilisation and embryonic development. Mar. Biol. 2010, 157, 2689-2702. [CrossRef]

85. Ericson, J.A.; Ho, M.A.; Miskelly, A.; King, C.K.; Virtue, P.; Tilbrook, B.; Byrne, M. Combined effects of two ocean change stressors, warming and acidification, on fertilization and early development of the Antarctic echinoid Sterechinus neumayeri. Polar Biol. 2011, 35, 1027-1034. [CrossRef]

86. Smith, K.E.; Byrne, M.; Deaker, D.; Hird, C.M.; Nielson, C.; Wilson-McNeal, A.; Lewis, C. Sea urchin reproductive performance in a changing ocean: Poor males improve while good males worsen in response to ocean acidification. Proc. $R$. Soc. B 2019, 286, 20190785. [CrossRef]

87. Aguirre-Martinez, G.V.; Owuor, M.A.; Garrido-Perez, C.; Salamanca, M.J.; Del Valls, T.A.; Martin-Diaz, M.L. Are standard tests sensitive enough to evaluate effects of human pharmaceuticals in aquatic biota? Facing changes in research approaches when performing risk assessment of drugs. Chemosphere 2015, 120, 75-85. [CrossRef]

88. Evans, A.D.; Nipper, M. Toxicity of phenanthrene and lindane mixtures to marine invertebrates. Environ. Toxicol. 2007, 22, 495-501. [CrossRef] [PubMed]

89. Arizza, V.; Di Fazio, G.; Celi, M.; Parrinello, N.; Vazzana, M. Cadmium, Copper and Tributyltin effects on fertilization of Paracentrotus lividus (Echinodermata). Ital. J. Anim. Sci. 2009, 8, 839-841. [CrossRef]

90. Christen, R.; Schackmann, R.W.; Shapiro, B.M. Elevation of the intracellular pH activates respiration and motility of sperm of the sea urchin, Strongylocentrotus purpuratus. J. Biol. Chem. 1982, 257, 14881-14890. [CrossRef]

91. Levitan, D.R.; Sewell, M.A.; Chia, F.S. Kinetics of fertilization in the sea urchin Strongylocentrotus franciscanus: Interaction of gamete dilution, age, and contact time. Biol Bull. 1991, 181, 371-378. [CrossRef]

92. Fabbrocini, A.; D'adamo, R. Motility of sea urchin Paracentrotus lividus spermatozoa in the post-activation phase. Aquac. Res. 2017, 48, 5526-5532. [CrossRef]

93. Palumbi, S.R. All males are not created equal: Fertility differences depend on gamete recognition polymorphisms in sea urchins. Proc. Natl. Acad. Sci. USA 1999, 96, 12632-12637. [CrossRef]

94. Darszon, A.; Guerrero, A.; Galindo, B.E.; Nishigaki, T.; Wood, C.D. Sperm-activating peptides in the regulation of ion fluxes, signal transduction and motility. Int. J. Dev. Biol. 2008, 52, 595-606. [CrossRef]

95. Krug, P.J.; Riffell, J.A.; Zimmer, R.K. Endogenous signaling pathways and chemical communication between sperm and egg J. Exp. Biol. 2009, 212, 1092-1100. [CrossRef]

96. Manzo, S.; Miglietta, M.L.; Rametta, G.; Buono, S.; Di Francia, G. Embryotoxicity and spermiotoxicity of nanosized ZnO for Mediterranean sea urchin Paracentrotus lividus. J. Hazard. Mater. 2013, 15, 254-255. [CrossRef]

97. Earnshaw, M.J.; Wilson, S.; Akberali, H.B.; Butler, R.D.; Marriott, K.R.M. The action of heavy-metals on the gametes of the marine mussel, Mytilus edulis. The effect of applied copper and zinc on sperm motility in relation to ultrastructural damage and intracellular metal localization. Mar. Environ. Res. 1986, 20, 261-278. [CrossRef]

98. Au, D.W.T.; Chiang, M.W.L.; Wu, R.S.S. Effects of cadmium and phenol on motility and ultrastructure of sea urchin and mussel spermatozoa. Arch. Environ. Contam. Toxicol. 2000, 38, 455-463. [CrossRef] [PubMed]

99. Au, D.W.T.; Reunov, A.A.; Wu, R.S.S. Reproductive impairment of sea urchins upon chronic exposure to cadmium. Part II: Effects on sperm development. Environ. Pollut. 2001, 111, 11-20. [CrossRef]

100. Asnicar, D.; Novoa-Abelleira, A.; Minichino, R.; Badocco, D.; Pastore, P.; Finos, L.; Munari, M.; Marin, M.G. When site matters: Metabolic and behavioural responses of adult sea urchins from different environments during long-term exposure to seawater acidification. Mar. Environ. Res. 2021, 169, 105372. [CrossRef] [PubMed] 